\title{
Palladium(0)-Catalyzed Synthesis of Unsaturated Polyesters from Bifunctional Vinyloxirane and Diacids
}

\author{
Toshio KoIZUmI, ${ }^{\dagger}$ Tadayoshi AKITA, and Takeshi ENDO* \\ Department of Applied Chemistry, The National Defense Academy, Hashirimizu, Yokosuka 239-8686, Japan \\ *Department of Polymer Science and Engineering, Yamagata University, Yonezawa 992-8510, Japan
}

(Received November 28, 2002; Accepted January 14, 2003)

\begin{abstract}
We found that the palladium(0)-catalyzed polyaddition of a bifunctional vinyloxirane, 1,4-bis(1methyl-2-vinylepoxyethyl)benzene (1), with diacids gave new unsaturated polyesters having pendant hydroxyl groups in good yields. The polyaddition was carried out in THF in the presence of a $\mathrm{Pd}(0)$ catalyst (5 $\mathrm{mol} \%$ for 1$)$. Among the diacids employed, adipic acid (3), fumaric acid (5), isophthalic acid (7), and terephthalic acid (9) could be used in the polyaddition of $\mathbf{1}$. Maleic acid and phthalic acid did not afford the corresponding polyesters. $\operatorname{The} \operatorname{Pd}(0)$-catalyzed polyaddition with 3, 5, 7, and 9 proceeded successfully when $\mathrm{PPh}_{3}$ was used as the ligand. 1,2-Bis(diphenylphosphino)ethane (dppe) was not effective. We also found that $p$-hydroxybenzoic acid (11), which has a hydroxyl and carboxyl groups within the same molecule, could be used in the $\operatorname{Pd}(0)$-catalyzed polyaddition of $\mathbf{1}$ and produced a new unsaturated polymer with an ether and ester moieties in the main chain. All the obtained polymers were soluble in organic solvents such as THF and dimethylsulfoxide (DMSO).
\end{abstract}

KEY WORDS Palladium(0)-Catalyzed Polymerization / Vinyloxirane / Polyaddition / Diacids / Unsaturated Polyester / Hydroxyl Group /

It is well known that unsaturated polyesters are prepared by polymerization of diols with maleic anhydride. Crosslinking of the polyesters are accomplished by radical copolymerization with vinyl monomers such as styrene. Polyesters with pendant hydroxyl groups were obtained by the polyaddition of bisoxirane derivatives with diacids. However, the polyaddition tends to afford solvent-insoluble polyesters because of crosslinking. ${ }^{1}$ Recently, Nishikubo ${ }^{2}$ and Klee ${ }^{3}$ reported that solvent-soluble polyesters with pendant hydroxyl groups could be obtained by polyaddition of bisoxirane derivatives and diacids.

Unsaturated polymers are important for synthesis of crosslinked polymers. Polymers with hydroxyl groups are also significant in reactive polymers and polymeric reagents. ${ }^{4}$ Therefore, unsaturated polyesters with pendant hydroxyl groups would be applicable as new reactive and functional polymers. However, it is very difficult to synthesize various such polymers by conventional methods. To our knowledge, the synthesis of unsaturated polyesters with hydroxyl groups in the side groups has not been reported. In this article, we describe the $\operatorname{Pd}(0)$-catalyzed synthesis of unsaturated polyesters from 1,4-bis(1-methyl-2vinylepoxyethyl)benzene (1) and diacids (Scheme 1). We have recently found that the palladium(0)-catalyzed polyaddition of bifunctional vinyloxiranes [ 1 and 1,4bis(2-vinylepoxyethyl)benzene (2)] with nucleophiles such as active methylene compounds and bisphenol

${ }^{\dagger}$ To whom correspondence should be addressed.

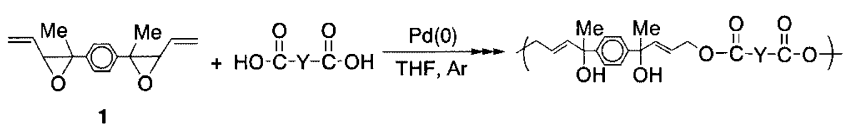

Scheme 1. Synthesis of unsaturated polyesters from $\mathbf{1}$ and diacids.

analogues afforded various unsaturated polymers having pendant hydroxyl groups. ${ }^{5-8}$ Consequently, we tried the application of the $\operatorname{Pd}(0)$-catalyzed polyaddition using diacids to the synthesis of unsaturated polyesters with pendant hydroxyl groups.

\section{EXPERIMENTAL}

\section{Measurement}

Fourier transfer infrared (FT-IR) spectra were measured on a JASCO FT/IR-230 spectrometer. ${ }^{1} \mathrm{H}$ and ${ }^{13} \mathrm{C}$ nuclear magnetic resonance (NMR) spectra were recorded on a Bruker-DMX 500 using dimethyl sulfoxide- $d_{6}\left(\mathrm{DMSO}-d_{6}\right)$ as a solvent and $\mathrm{Me}_{4} \mathrm{Si}$ as an internal standard. Gel permeation chromatography (GPC) measurements were performed on a Shimadzu HPLC LC-6A system equipped with two columns (Shim-pack GPC-802 and GPC-804) using tetrahydrofuran (THF) as an eluent at $45^{\circ} \mathrm{C}$. The GPC was calibrated against standard polystyrene samples.

\section{Materials}

Extra-pure grade reagents were used without further purification. Bifunctional vinyloxirane 1 was prepared by the method reported in our previous paper. 6 THF 
Table I. $\operatorname{Pd}(0)$-Catalyzed Polyaddition of $\mathbf{1}$ with Diacids $(\mathbf{3}, \mathbf{5}, \mathbf{7}$, and 9)

\begin{tabular}{|c|c|c|c|c|c|c|c|}
\hline Run & $\operatorname{Diacid}(\mathrm{Y}=)$ & Temp. $\left({ }^{\circ} \mathrm{C}\right)$ & Time & $\operatorname{Pd}(0)$ & $M_{\mathrm{n}}{ }^{\mathrm{a}}$ & $M_{\mathrm{w}} / M_{\mathrm{n}}^{\mathrm{a}}$ & Yield (\%) \\
\hline 1 & $-\left(\mathrm{CH}_{2}\right)_{4}-\mathbf{3}$ & r.t. & $24 \mathrm{~h}$ & $\mathrm{Pd}\left(\mathrm{PPh}_{3}\right)_{4}$ & 1400 & 2.35 & 92 \\
\hline 2 & 3 & 60 & $6 \mathrm{~h}$ & $\mathrm{Pd}\left(\mathrm{PPh}_{3}\right)_{4}$ & 2800 & 2.29 & 81 \\
\hline 3 & 3 & r.t. & $24 \mathrm{~h}$ & $\mathrm{Pd}_{2}(\mathrm{dba})_{3} / \mathrm{dppe}^{\mathrm{c}}$ & - & - & 0 \\
\hline 4 & $\Gamma^{5}$ & r.t. & $8 \mathrm{~d}$ & $\mathrm{Pd}\left(\mathrm{PPh}_{3}\right)_{4}$ & 940 & 2.97 & 95 \\
\hline 5 & 5 & 60 & $24 \mathrm{~h}$ & $\mathrm{Pd}\left(\mathrm{PPh}_{3}\right)_{4}$ & 1900 & 3.37 & 98 \\
\hline 6 & 5 & 60 & $24 \mathrm{~h}$ & $\mathrm{Pd}_{2}(\mathrm{dba})_{3} / \mathrm{dppe}^{\mathrm{c}}$ & - & - & 0 \\
\hline 7 & (0) 7 & r.t. & $24 \mathrm{~h}$ & $\mathrm{Pd}\left(\mathrm{PPh}_{3}\right)_{4}$ & 2400 & 2.40 & 86 \\
\hline 8 & 7 & r.t. & $24 \mathrm{~h}$ & $\mathrm{Pd}_{2}(\mathrm{dba})_{3} / \mathrm{dppe}^{\mathrm{c}}$ & - & - & 0 \\
\hline 9 & $-(0)-9$ & r.t. & $24 \mathrm{~h}$ & $\mathrm{Pd}\left(\mathrm{PPh}_{3}\right)_{4}$ & 4300 & 2.58 & 99 \\
\hline 10 & 9 & r.t. & $24 \mathrm{~h}$ & $\mathrm{Pd}_{2}(\mathrm{dba})_{3} / \mathrm{dppe}^{\mathrm{c}}$ & - & - & 0 \\
\hline 11 & 9 & 60 & $6 \mathrm{~h}$ & $\mathrm{Pd}_{2}(\mathrm{dba})_{3} / \mathrm{dppe}^{\mathrm{c}}$ & - & - & 0 \\
\hline
\end{tabular}

${ }^{a}$ Estimated by GPC(based on PSt). ${ }^{b}$ Insoluble in toluene. ${ }^{c} \mathrm{Ph}_{2} \mathrm{PCH}_{2} \mathrm{CH}_{2} \mathrm{PPh}_{2}$.

used as the solvent for the $\operatorname{Pd}(0)$-catalyzed polyaddition was distilled from sodium/benzophenone ketyl under nitrogen prior to use.

Pd(0)-Catalyzed Polyaddition of Bifunctional Vinyloxirane (1) with Diacids: A Typical Procedure. To a solution of $\mathrm{Pd}\left(\mathrm{PPh}_{3}\right)_{4}(0.058 \mathrm{~g}, 0.05 \mathrm{mmol})$ in THF $(2 \mathrm{~mL})$ terephthalic acid $(9 ; 0.166 \mathrm{~g}, 1.0 \mathrm{mmol})$ was added. To this a solution of bifunctional vinyloxirane $1(0.242 \mathrm{~g}, 1.0 \mathrm{mmol})$ in THF $(1 \mathrm{~mL})$ was added. The mixture was stirred at room temperature under an Ar atmosphere. After $24 \mathrm{~h}$, the reaction mixture was poured into toluene $(100 \mathrm{~mL}$ ) to precipitate the polymer (run 9 in Table I). The resulting polymer (10) was filtered off, washed with toluene, and dried in vacuo $(0.407 \mathrm{~g}, 99 \%)$ giving a yellow solid: IR (KBr): 3467, 3030, 2976, 2877, 1714, 1269, 1103, $968 \mathrm{~cm}^{-1}$. ${ }^{1} \mathrm{H}$ NMR (DMSO$\left.d_{6}, \delta\right): 1.54\left(\mathrm{CH}_{3}, \mathrm{~s}, 3 \mathrm{H}\right), 4.85\left(-\mathrm{CH}_{2}-, \mathrm{s}, 4 \mathrm{H}\right), 5.44$ $(\mathrm{OH}, \mathrm{s}, 2 \mathrm{H}), 5.88-5.92\left(-\mathrm{CH}=\mathrm{CHCH}_{2}-, \mathrm{m}, 2 \mathrm{H}\right), 6.17$ $(-\mathrm{CCH}=\mathrm{CH}-, \mathrm{d}, J=15.2 \mathrm{~Hz}, 1 \mathrm{H}), 7.41(\mathrm{ArH}, \mathrm{s}, 4 \mathrm{H})$, $8.08(\mathrm{ArH}, \mathrm{s}, 4 \mathrm{H}) .{ }^{13} \mathrm{C}$ NMR (DMSO- $d_{6}, \delta$ ): 30.3, $65.7,72.9,120.4,124.9,129.9,134.0,143.1,146.1$, 165.2.

Polyester 4, a pale yellow solid: IR (KBr): 3448 , $3037,2974,2875,1728,1362,1176,1076,974 \mathrm{~cm}^{-1}$. ${ }^{1} \mathrm{H}$ NMR (DMSO- $\left.d_{6}, \delta\right): 1.49\left(\mathrm{CH}_{3}, \mathrm{~s}, 6 \mathrm{H}\right), 1.52$ $\left(-\mathrm{CH}_{2}-, \mathrm{s}, 4 \mathrm{H}\right), 2.31\left(-\mathrm{CH}_{2}-, \mathrm{s}, 4 \mathrm{H}\right), 4.52\left(-\mathrm{CH}_{2}-\right.$, $\mathrm{d}, J=5.9 \mathrm{~Hz}, 4 \mathrm{H}), 5.35(\mathrm{OH}, \mathrm{s}, 2 \mathrm{H}), 5.68-5.74$ $\left(-\mathrm{CH}=\mathrm{CHCH}_{2}-, \mathrm{m}, 2 \mathrm{H}\right), 6.01(-\mathrm{CCH}=\mathrm{CH}-, \mathrm{d}, J=$ $15.5 \mathrm{~Hz}, 2 \mathrm{H}$ ), 7.35 (ArH, s, $4 \mathrm{H}$ ). ${ }^{13} \mathrm{C}$ NMR (DMSO$\left.d_{6}, \delta\right): 24.2,30.0,33.4,64.3,72.8,120.6,125.0,142.6$, 146.1, 172.9.

Polyester 6, a pale yellow solid: IR $(\mathrm{KBr})$ : 3440 , 3030, 2976, 2875, 1718, 1300, 1157, $976 \mathrm{~cm}^{-1} .{ }^{1} \mathrm{H}$ NMR (DMSO- $\left.d_{6}, \delta\right)$ : $1.51\left(\mathrm{CH}_{3}, \mathrm{~s}, 3 \mathrm{H}\right), 4.69\left(\mathrm{CH}_{2}\right.$, $\mathrm{d}, J=4.4 \mathrm{~Hz}, 4 \mathrm{H}), 5.39(\mathrm{OH}, \mathrm{s}, 2 \mathrm{H}), 5.77-5.81$
$\left(-\mathrm{CH}=\mathrm{CHCH}_{2}-, \mathrm{m}, 2 \mathrm{H}\right), 6.10(-\mathrm{CCH}=\mathrm{CH}-, \mathrm{d}, J=$ $15.4 \mathrm{~Hz}, 2 \mathrm{H}), 6.80(-\mathrm{CH}=\mathrm{CH}-$, s, $2 \mathrm{H}), 7.38(\mathrm{ArH}, \mathrm{s}$, $4 \mathrm{H}) .{ }^{13} \mathrm{C}$ NMR (DMSO- $d_{6}, \delta$ ): 30.0, 65.5, 72.8, 120.0, 125.0, 133.6, 143.2, 146.1, 164.4 .

Polyester 8, a white solid: IR (KBr): 3442, 3030, 2974, 2877, 1722, 1232, 1074, $966 \mathrm{~cm}^{-1}$. ${ }^{1} \mathrm{H}$ NMR $\left(\right.$ DMSO- $\left.d_{6}, \delta\right): 1.54\left(\mathrm{CH}_{3}, \mathrm{~s}, 6 \mathrm{H}\right), 4.85\left(-\mathrm{CH}_{2}-\right.$, d, $J=5.2 \mathrm{~Hz}, 4 \mathrm{H}), 5.43(\mathrm{OH}, \mathrm{s}, 2 \mathrm{H}), 5.87-5.92$ $\left(-\mathrm{CH}=\mathrm{CHCH}_{2}-, \mathrm{m}, 2 \mathrm{H}\right), 6.17(-\mathrm{CCH}=\mathrm{CH}-, \mathrm{d}, J=$ $15.4 \mathrm{~Hz}, 2 \mathrm{H}), 7.41$ (ArH, s, 4 H), 7.65-7.68 (ArH, m, $1 \mathrm{H}), 8.20(\mathrm{ArH}, \mathrm{d}, J=7.6 \mathrm{~Hz}, 2 \mathrm{H}), 8.48(\mathrm{ArH}, \mathrm{s}$, $1 \mathrm{H}) .{ }^{13} \mathrm{C}$ NMR (DMSO- $d_{6}, \delta$ ): 30.0, 65.7, 72.9, 120.4, 125.1, 128.5, 130.2, 131.0, 134.0, 143.2, 146.1, 165.0 .

Polymer 12, a pale yellow solid: IR (KBr): 3427 , 3032, 2976, 2931, 2871, 1703, 1604, 1254, 1169, 1105 , $972 \mathrm{~cm}^{-1} .{ }^{1} \mathrm{H}$ NMR (DMSO- $\left.d_{6}, \delta\right): 1.56\left(\mathrm{CH}_{3}, \mathrm{~s}, 6 \mathrm{H}\right)$, $4.66\left(-\mathrm{CH}_{2}-\right.$, s, $\left.2 \mathrm{H}\right), 4.80\left(-\mathrm{CH}_{2}-\right.$, s, $\left.2 \mathrm{H}\right), 5.42(\mathrm{OH}$, s, $2 \mathrm{H}), 5.88-5.91\left(-\mathrm{CH}=\mathrm{CHCH}_{2}-\right.$, m, $\left.2 \mathrm{H}\right), 6.13-6.18$ $(-\mathrm{CCH}=\mathrm{CH}-, \mathrm{m}, 2 \mathrm{H}), 7.07(\mathrm{ArH}, \mathrm{d}, J=7.8 \mathrm{~Hz}, 2 \mathrm{H})$, 7.41 (ArH, s, 4 H), $7.94(\mathrm{ArH}, \mathrm{d}, J=8.1 \mathrm{~Hz}, 2 \mathrm{H})$. ${ }^{13} \mathrm{C}$ NMR (DMSO- $d_{6}, \delta$ ): $30.0,67.4,68.5,72.9,115.1$, $120.9,122.3,125.1,131.6,142.6,146.2,162.6,165.5$.

\section{RESULTS AND DISCUSSION}

First, the $\operatorname{Pd}(0)$-catalyzed polyaddition of bifunctional vinyloxirane $\mathbf{1}$ with adipic acid (3) and fumaric acid (5) was carried out in THF under an Ar atmosphere. The resulting polymers were isolated by pouring the reaction mixture into toluene. The results are summarized in Table I. When $\mathrm{Pd}_{2}(\mathrm{dba})_{3} \cdot \mathrm{CHCl}_{3}$ (where dba is dibenzylideneacetone)/1,2-bis(diphenylphosphino)ethane (dppe) was used as a catalyst, the corresponding polymers from $\mathbf{3}$ and $\mathbf{5}$ were not obtained (runs 3 and 6). On the other hand, the polyaddi- 
Table II. Pd(0)-Catalyzed Polyaddition of 1 with $p$-Hydroxybenzoic Acid (11)

\begin{tabular}{|c|c|c|c|c|c|c|}
\hline & $=\overbrace{0}^{\mathrm{Me}}{ }_{1}^{\mathrm{O}} \overbrace{0}^{\mathrm{Me}}=$ & $\mathrm{HO}_{11}^{\mathrm{O}-\stackrel{\mathrm{C}}{\mathrm{C}}-\mathrm{OH}}$ & $\frac{(5 \mathrm{~mol} \%)}{\mathrm{Ar}, 24 \mathrm{~h}}$ & Me & $\mathrm{N}_{12}$ & \\
\hline Run & $\operatorname{Pd}(0)$ & Temp. $\left({ }^{\circ} \mathrm{C}\right)$ & Time(h) & $M_{\mathrm{n}}{ }^{\mathrm{a}}$ & $M_{\mathrm{w}} / M_{\mathrm{n}}{ }^{\mathrm{a}}$ & Yield $(\%)^{b}$ \\
\hline 1 & $\mathrm{Pd}\left(\mathrm{PPh}_{3}\right)_{4}$ & r.t. & 24 & 2700 & 1.76 & 100 \\
\hline 2 & $\mathrm{Pd}\left(\mathrm{PPh}_{3}\right)_{4}$ & 60 & 6 & 3200 & 2.11 & 100 \\
\hline 3 & $\mathrm{Pd}_{2}(\mathrm{dba})_{3} / \mathrm{dppe}^{\mathrm{c}}$ & r.t. & 24 & - & - & 0 \\
\hline 4 & $\mathrm{Pd}_{2}(\mathrm{dba})_{3} / \mathrm{dppe}^{\mathrm{c}}$ & 60 & 6 & 3900 & 2.27 & 96 \\
\hline
\end{tabular}

${ }^{a}$ Estimated by GPC(based on PSt). ${ }^{b}$ Insoluble in toluene. ${ }^{\mathrm{C}} \mathrm{Ph}_{2} \mathrm{PCH}_{2} \mathrm{CH}_{2} \mathrm{PPh}_{2}$.

tion using $\mathrm{Pd}\left(\mathrm{PPh}_{3}\right)_{4}$ gave the desired polymers in good yields. ${ }^{9}$ The polyaddition of $\mathbf{1}$ and $\mathbf{3}$ afforded the unsaturated polyester (4) in a $92 \%$ yield [number-average molecular weight $\left(M_{\mathrm{n}}\right)=1400$; run 1]. Polyester 4 with a higher $M_{\mathrm{n}}$ value was obtained by polymerization at $60^{\circ} \mathrm{C}$ for $6 \mathrm{~h}\left(M_{\mathrm{n}}=2800\right.$; run 2). Vinyloxirane $1 \mathrm{did}$ not react with 3 in the absence of $\mathrm{Pd}\left(\mathrm{PPh}_{3}\right)_{4}$ under the same conditions. The $M_{\mathrm{n}}$ values of polyester 6 obtained from fumaric acid (5) were lower than those of 4 (runs 4 and 5). The polyaddition of $\mathbf{1}$ and $\mathbf{5}$ was carried out in THF at room temperature for $8 \mathrm{~d}$ and gave the desired product 6. However, the $M_{\mathrm{n}}$ value was low $\left(M_{\mathrm{n}}=940\right)$. The $M_{\mathrm{n}}$ value of the obtained polyester 6 was 1900 , after polymerization even at the elevated temperature $\left(60{ }^{\circ} \mathrm{C}\right)$ for $24 \mathrm{~h}$. Thus, the $\operatorname{Pd}(0)$-catalyzed polyaddition of 1 proceeded more effectively when adipic acid was employed. The polyaddition of $\mathbf{1}$ was also examined using maleic acid instead of $\mathbf{5}$, but the corresponding polyester was not obtained. In addition, although the polyaddition of $\mathbf{3}$ and $\mathbf{5}$ was performed by use of 1,4-bis(2-vinylepoxyethyl)benzene (2) under various conditions, the desired polyesters were not produced, probably due to $\beta$-hydrogen elimination of the $\pi$-allylpalladium intermediate generated by oxidative addition of $\operatorname{Pd}(0)$ to $2 ., 6$

The structures of polyesters 4 and $\mathbf{6}$ were determined on the basis of the IR and NMR spectra. The methylene protons $\left(-\mathrm{CH}_{2}-\mathrm{O}-\right)$ of $\mathbf{4}$ and $\mathbf{6}$ were observed at 4.52 and $4.69 \mathrm{ppm}$, respectively. In addition, signals due to the vinyl proton $(-\mathrm{CCH}=\mathrm{CH}-)$ of $\mathbf{4}$ and $\mathbf{6}$ appeared at 6.01 and $6.10 \mathrm{ppm}$, respectively. The observation of these protons reveals that the polyaddition proceeded accompanying carbon-oxygen bond cleavage of the oxirane ring. The stereochemistries of $\mathbf{4}$ and $\mathbf{6}$ were confirmed as $E$ configurations by the coupling constant of the vinyl proton ( $-\mathrm{CCH}=\mathrm{CH}-$ ); the $J$ values of $\mathbf{4}$ and 6 were 15.5 and $15.4 \mathrm{~Hz}$, respectively. The $Z$-isomers were detected neither in the ${ }^{13} \mathrm{C}$ NMR spectra nor in the ${ }^{1} \mathrm{H}$ NMR spectra of $\mathbf{4}$ and $\mathbf{6}$, similarly to the polyaddition of 1 and carbon nucleophiles., ${ }^{5}$ The IR spectra of $\mathbf{4}$ and $\mathbf{6}$ showed the characteristic absorptions based on the hydroxyl groups around 3450 and $3440 \mathrm{~cm}^{-1}$, respectively. Furthermore, the ester groups of $\mathbf{4}$ and
6 were observed around 1730 and $1720 \mathrm{~cm}^{-1}$, respectively. From these NMR and IR spectral data, we confirmed that the $\operatorname{Pd}(0)$-catalyzed polyaddition of $\mathbf{1}$ with $\mathbf{3}$ and $\mathbf{5}$ produced the desired unsaturated polyesters with pendant hydroxyl groups.

Second, we examined the $\operatorname{Pd}(0)$-catalyzed polyaddition of $\mathbf{1}$ using aromatic diacids [phthalic acid, isophthalic acid (7), and terephthalic acid (9)]. Among the aromatic diacids employed, phthalic acid did not give the corresponding polyester. Neither phthalic acid nor maleic acid was suitable for the polyaddition with $\mathbf{1}$. The polyaddition of $\mathbf{1}$ with $\mathbf{7}$ and $\mathbf{9}$ was carried out in THF at room temperature for $24 \mathrm{~h}$. When dppe was used as a phosphine ligand, the desired polyesters were not obtained (runs 8 and 10). On the other hand, $\mathrm{PPh}_{3}$ gave the corresponding polyesters in good yields. In the polyaddition of $\mathbf{1}$ with $\mathbf{7}$, polyester $\mathbf{8}$ was formed in an $86 \%$ yield $\left(M_{\mathrm{n}}=2400\right.$; run 7$)$. The $M_{\mathrm{n}}$ value of the obtained polymer $\mathbf{1 0}$ from $\mathbf{9}$ was higher than that of $8\left(M_{\mathrm{n}}=4300\right.$; run 9$)$. Thus, the $\operatorname{Pd}(0)$-catalyzed polyaddition of 1 proceeded more effectively when $\mathbf{9}$ was employed. The polyaddition with phthalic acid, 7, and 9 was largely affected by the position $(o-, m-$, and $p$-) of two carboxyl groups on the benzene ring; the $M_{n}$ values and yields of the polymers increased in the following order: phthalic acid $(o-)<<7(m-)<9(p-)$.

Finally, the $\operatorname{Pd}(0)$-catalyzed polyaddition of 1 was examined by use of $p$-hydroxybenzoic acid (11). Table II shows the results. In the polyaddition at room temperature for $24 \mathrm{~h}$ with $\mathrm{Pd}\left(\mathrm{PPh}_{3}\right)_{4}$, the desired polymer 12 was obtained quantitatively $\left(M_{\mathrm{n}}=2700\right.$; run 1). The $M_{\mathrm{n}}$ value of $\mathbf{1 2}$ obtained by polymerization at $60^{\circ} \mathrm{C}$ for $6 \mathrm{~h}$ was somewhat higher $\left(M_{\mathrm{n}}=3200\right.$; run 2$)$. The polyaddition at room temperature using $\mathrm{Pd}_{2}(\mathrm{dba})_{3}$. $\mathrm{CHCl}_{3} /$ dppe as a catalyst did not afforded polymer $\mathbf{1 2}$ (run 3), whereas the polyaddition at the elevated temperature $\left(60^{\circ} \mathrm{C}\right)$ proceeded efficiently and gave the desired polymer 12 in a $96 \%$ yield $\left(M_{\mathrm{n}}=3900\right.$; run 4$)$, contrary to the polyaddition with 9 (run 11 in Table I). The structure of $\mathbf{1 2}$ was confirmed with IR and NMR spectra. A new type of unsaturated polymer $\mathbf{1 2}$ having an ether and ester moieties in the main chain could be obtained by the $\operatorname{Pd}(0)$-catalyzed polyaddition of 1 with 
11 having a hydroxyl and carboxyl groups. This fact indicates that the $\operatorname{Pd}(0)$-catalyzed polyaddition with $\mathbf{1}$ is a useful method for the synthesis of unsaturated polymers having different functional groups in the main chain.

\section{CONCLUSION}

We found that the $\operatorname{Pd}(0)$-catalyzed polyaddition of bifunctional vinyloxirane 1 and diacids $(\mathbf{3}, \mathbf{5}, 7$, and 9) gave unsaturated polyesters with pendant hydroxyl groups. All of the obtained polyesters were soluble in organic solvents such as dimethylsulfoxide (DMSO) and THF. In addition, we found that nucleophile 11, which has a hydroxyl and carboxyl groups within the same molecule, could be used in the $\operatorname{Pd}(0)$-catalyzed polyaddition of 1 to synthesize a new unsaturated polymer with an ether and ester moieties in the main chain.

\section{REFERENCES}

1. P. J. Madec and E. Maréchal, Adv. Polym. Sci., 71, 153 (1985).
2. A. Suzuki, A. Kameyama, and T. Nishikubo, Kobunshi Ronbunshu, 53, 522 (1996).

3. J. E. Klee, F. Claußen, and H. H. Hörhold, Polym. Bull., 35, 79 (1995).

4. A. Akelah and D. C. Sherrington, Chem. Rev., 81, 557 (1981).

5. T. Koizumi, J. Sakamoto, Y. Gondo, and T. Endo, Macromolecules, 35, 2898 (2002).

6. T. Koizumi, J. Sakamoto, Y. Gondo, and T. Endo, J. Polym. Sci., Part A: Polym. Chem., 40, 2487 (2002).

7. T. Koizumi, T. Imai, and T. Endo, J. Polym. Sci., Part A: Polym. Chem., 41, 476 (2003).

8. For examples of the $\mathrm{Pd}(0)$-catalyzed reaction of vinyloxiranes with nucleophiles:

a) J. Tsuji, H. Kataoka, and Y. Kobayashi, Tetrahedron Lett., 22, 2575 (1981).

b) B. M. Trost and G. A. Molander, J. Am. Chem. Soc., 103, 5969 (1981).

9. For the $\operatorname{Pd}(0)$-catalyzed reaction of vinyloxirane with carboxylic acids:

D. R. Deardorff, D. C. Myles, and K. D. MacFerrin, Tetrahedron Lett., 26, 5615 (1985). 